\title{
Testicular expression of the TGF- $\beta 1$ system and the control of Leydig cell proliferation
}

\author{
Gonzalez Candela Rocio $^{1 *}$, Calandra Ricardo Saul ${ }^{2}$, Gonzalez-Calvar Silvia Ines ${ }^{2,3}$ \\ ${ }^{1}$ Research Center of Biomedical Biotechnology, Environmental and Diagnostic Studies, Maimónides University, Buenos Aires, Ar- \\ gentina \\ ${ }^{2}$ Institute of Biology and Experimental Medicine, National Council for Scientific and Technical Research, Buenos Aires, Argentina \\ ${ }^{3}$ School of Medicine, Buenos Aires University, Buenos Aires, Argentina \\ Email: "gonzalez.candela@maimonides.edu, ricardoscalandra@gmail.com, gonsi@fmed.uba.ar
}

Received 24 June 2013; revised 25 July 2013; accepted 15 August 2013

Copyright (C) 2013 Gonzalez Candela Rocio et al. This is an open access article distributed under the Creative Commons Attribution License, which permits unrestricted use, distribution, and reproduction in any medium, provided the original work is properly cited.

\begin{abstract}
Transforming growth factor beta 1 (TGF- $\beta 1$ ) is a key regulator that modulates male reproductive function. Testicular TGF- $\beta 1$ modulates the steroidogenesis of Leydig cells, the organization of peritubular myoid cells, testis development and spermatogenesis. Several studies have indicated that TGF- $\beta 1$ is involved in the tight balance between proliferative and apoptotic responses in the Leydig cells. In the present review, we summarize the direct effects of this cytokine in Leydig cells under normal and pathological conditions. We analyze the effect of TGF- $\beta 1$ in Leydig cells depending on the type of receptors involved in the signaling pathway of TGF- $\beta 1$. Our group has been analyzing the canonical and non canonical intracellular signaling pathways of TGF- $\beta 1$ that are involved in the expression of proliferative and apoptotic markers in Leydig cells. On the basis of our studies and from those of other authors we conclude that the balance between the expression of TGF- $\beta 1$ receptors and co receptors is of relevance in Leydig cell physiology and pathophisiology.
\end{abstract}

Keywords: TGF- $\beta 1$; Leydig; ALK; Endoglin

\section{INTRODUCTION}

The normal function of the testis has long been recognized to be dependent on gonadotropins hormones. Numerous reports over the past years have clearly indicated that locally produced factors may play an important role in the regulation of Leydig cell functions. In this context, many factors produced locally in the testes that act in a paracrine and/or autocrine manner are able to have plei-

*Corresponding author. otropic actions on Leydig cell homeostasis. Particularly, the transforming growth factor beta (TGF- $\beta$ ) family members play important roles in Leydig cell differentiation, proliferation and secretory functions. This review will focus on two aspects: first, the localization of TGF- $\beta 1$ system in the testis of different species and second, the action and signaling pathways of the TGF- $\beta 1$ involved in a mechanism that controls Leydig cell proliferation.

\subsection{The TGF- $\beta$ Family}

The TGF- $\beta$ family controls diverse cellular processes including cell proliferation, differentiation, migration and apoptosis [1]. TGF- $\beta$ family comprises more than 30 proteins that share between $30 \%$ to $80 \%$ sequence homology [1]. The best characterized members of this family include five isoforms of TGF- $\beta$ (TGF- $\beta 1$-5), inhibins, activins, bone morphogenetic proteins (BMPs), anti-Mullerian Hormone (AMH) and growth and differentiation factors (GDFs) [2,3]. TGF- $\beta$ members have an important role during embryogenesis, organogenesis and maintenance of tissue homeostasis during adult life [4]. In addition, deregulation of the TGF- $\beta$ signaling has been implicated in the progression of diseases such as cancer and autoimmune fibrosis [5].

In reproductive tissues, TGF- $\beta$ members regulate the development of the gonads and accessory sex glands, spermatogenesis, immunoregulation of pregnancy, embryo implantation and placental development [6].

\subsection{Localization of TGF- $\beta 1$ in the Testis}

Five isoforms of TGF- $\beta$ encoded by different genes have been described [7-9]. TGF- $\beta 1$, TGF- $\beta 2$ and TGF- $\beta 3$ are expressed in the mammalian testis whereas TGF- $\beta 4$ and 5 are expressed in birds and toads [6]. Particularly, testicular TGF- $\beta 1$ modulates a variety of cellular processes, 
comprising the secretory function of Leydig cells, the organization of peritubular myoid cells, testis development and spermatogenesis [9-11]. TGF- $\beta$ has been detected both in somatic cells (Leydig cells, peritubular myoid cells and Sertoli cells) and germ cells from different species including pigs, rats, mice, hamsters and humans [12-15]. It has been also demonstrated that different factors such as age, photoperiod or pathological conditions modulate the expression of TGF- $\beta 1$ in the testis [16-18].

\subsection{The TGF- $\beta$ Receptors in the Testis}

Five type II and seven type I receptors that bind members of the TGF- $\beta$ family have been identified in mammals [19-21]. These receptors are transmembrane proteins with an intracellular serine/threonine kinase domain. TGF- $\beta$ type II receptors include the receptors for activin (ActR-IIA, ActR-IIB), BMPs (BMPRII), AMH (AMHRII) and TGF- $\beta$ (TGF- $\beta$ RII) [3]. TGF- $\beta$ type I receptors (TGF- $\beta \mathrm{RI}$ ) comprise the activin like receptor kinase (ALK) 1 - 7, which can be classified in three groups according to their sequence. The first group includes ALK5, ALK-4, ALK-7 and GDFs receptor. The second group consists of the two BMP type I receptors, ALK-3 and ALK-6. Finally, in the third group, are included the ALK1 and ALK-2 receptors [22]. The receptors involved in the TGF- $\beta 1$ action are the TGF- $\beta$ RII and TGF- $\beta$ RI, particularly, ALK-1 and ALK-5 [9,23-25]. The presence of TGF- $\beta$ RII and ALK-5 receptors has been extensively demonstrated in Leydig cells, Sertoli cells and germ cells from mice [14], rats [26], boars [18], pigs [27], hamsters [15] and humans $[13,28]$. ALK-1 receptor was recently observed in Leydig cells from mice [14], hamsters [15] and humans [28].

Other receptors capable of binding TGF- $\beta$ members are TGF- $\beta$ receptor type III (TGF- $\beta$ RIII) or betaglycan [29] and the co-receptor endoglin [30,31]. The presence of TGF- $\beta$ RIII has been characterized in the testicular cells [32] but endoglin receptor was characterized primarily in endothelial cells [33]. Recently, the expression of the protein and mRNA of endoglin has been reported in Leydig cells from human and mouse testis [14,28]. The pattern of expression of the TGF- $\beta$ receptors in a given cell leads to different responses exerted by TGF- $\beta 1$ (see below).

\subsection{Canonical and Non-Canonical TGF- $\beta 1$ Signal Transduction Pathway}

The TGF- $\beta$ receptors have the ability to associate as homomeric and heteromeric complexes. In this context, TGF- $\beta$ RII forms homodimers regardless of TGF- $\beta$ binding and is constitutively autophosphorylated [34,35]. TGF$\beta \mathrm{RI}$ also forms homodimers independently of ligand and binding. Both ALK-1 and ALK-5 are not able to effi- ciently bind to the ligand, except when they are associated with the TGF- $\beta$ RII. Therefore, the binding of TGF$\beta 1$ to TGF- $\beta$ RII induces the recruitment and phosphorylation of ALK-1 and/or ALK-5 receptors and triggers the intracellular signal transduction through the Smad proteins (namely canonical mechanism) [4]. Eight different Smad proteins are encoded by the human and mouse genome [4]. Only five Smad proteins (Smad1, Smad2, Smad3, Smad5 and Smad8) act as a substrate for the TGF- $\beta$ receptors and are called R-Smads [5]. In this context, ALK-1 receptor signals via the phosphorylation of Smads $1 / 5$ and ALK-5 receptor signals via the phosphorylation of Smads 2/3 [8]. This process induces the transduction of the extracellular signal of TGF- $\beta 1$ activating downstream gene transcription [19,20,36,37].

The presence of Smad proteins in the testis has not been thoroughly studied. At present, it has been described in rats, i.e. the expression of the Smads 1, 2 and 3 in Leydig cells, Sertoli cells and germ cells [38,39]. In mouse postnatal testis, Smad1 has been detected in spermatocytes and round spermatids [40]. In the prepubertal mouse testis, the expression of Smad5 has been reported in spermatogonia cells [41]. In the human testis, Smad 1, 2, 3 and 5 have been localized in Leydig cells and seminiferous tubules [28,42].

Besides these intracellular mechanisms involving Smad proteins, TGF- $\beta 1$ exerts its action via non-smads proteins (namely non-canonical mechanism), particularly, JNK (Jun N-terminal kinase), p38 MAPK (mitogen-activated protein kinase p38) and ERK (extracellular-signal-regulated kinase) [43-45]. The first evidence of this mechanism comes from observations in which TGF- $\beta 1$ can activate the ERK signalling pathway promoting the activation of p21 (cell cycle inhibitory factor) in intestine and lung epithelial cells from rats [46]. At present, the best characterized TGF- $\beta 1$ signalling pathway that does not involve Smad proteins is the JNK and p38 MAPK pathway [47]. A direct demonstration of this mechanism is based on results performed in murine mammary epithelial cells with a mutation in the TGF- $\beta$ RI receptor at the binding and phosporilating Smads sites. It was observed that this mutated receptor is capable to induce an intracellular response in the presence of TGF- $\beta 1$ activating JNK and p38 MAPK pathways and leading to cell apoptosis [48, 49].

\section{INVOLVEMENT OF TGF- $\beta 1$ IN LEYDIG CELL PROLIFERATION}

TGF- $\beta 1$ exerts a crucial role in cell proliferation, differentiation and apoptosis. Although the mechanism of TGF$\beta 1$ signalling has been studied in different experimental conditions, the action of this cytokine in testis homeostasis has been poorly analyzed. It is well known that TGF$\beta 1$ inhibits the growth of most cell types, including epi- 
thelial cells, endothelial cells, fibroblasts and hematopoietic cells [50]. On the other hand, it has been observed that TGF- $\beta 1$ is able to stimulate cell proliferation in skin fibroblasts and endothelial cells [50]. In this context, it has been shown the activation of the TGF- $\beta$ RII and subsequently of ALK-5 and Smad2/3 by TGF- $\beta 1$ leads to a regulation of the gene promoters for the cyclin dependent kinases (CDK) to suppress their transcription [50]. Smad proteins are responsible for the transcriptional activation of the two major cyclin inhibitors: p15 and p21. Both are responsible for inhibiting the activity of CDK proteins that allow the progression from G1 to S phase of the cell cycle, leading to cell cycle arrest in G1 phase [4,50]. In human prostate cells, gastric cells and astrocytes it was observed that the incubation with TGF- $\beta 1$ promotes apoptosis by enhancing the levels of p15 and p21 [51-54]. In ovarian tumor cells, the treatment with TGF- $\beta$ leads to an increase in p15 levels and phosphorylation of Smad2 [55]. In the testis, it has been described that the incubation of hamster Leydig cells with TGF- $\beta 1$ stimulated p15 expression in a mechanism that involves the participation of ALK-5 receptor and activation of p38 MAPK [15]. In line with this, Wu et al. [45] observed that TGF- $\beta 1$ activates the $\mathrm{p} 38$ pathway leading to cell apoptosis in murine podocytes. There is no direct evidence that TGF- $\beta 1$ via p38 MAPK induces apoptosis of Leydig cells, although exists different reports that propose the participation of this MAPK in the apoptosis of germ cells in rodents [56]. However, studies reported by Gonzalez et al. [15], indicated that the Leydig cells from hamsters with maximal testicular photoperiodic regression are quiescent and express a marked increased of p15 which leads to an arrest of cellular cycle and not necessarily leads the cells to apoptosis.

It is important to point out, that TGF- $\beta 1$ exerts bifunctional effects on cell proliferation, a mechanism highly described in endothelial cells [57]. In this experimental model, Lebrin et al. [57] showed that TGF- $\beta 1$ is able to induce or inhibit cell proliferation. In these "in vitro" studies, low doses of TGF- $\beta 1$ stimulated endothelial cell proliferation, whereas high doses of TGF- $\beta 1$ inhibited this response $[33,57]$. The results obtained in endothelial cells, showed that the bifunctional effect of TGF- $\beta 1$ is the result of the balance between the expression of ALK5 and ALK-1 receptors. Whereas ALK-5 is responsible for the inhibition of proliferation, ALK-1 has the opposite effect [57]. In line with this, the co-receptor endoglin plays a fundamental role. Extracellular and cytoplasmic domains of endoglin interact with ALK-1 receptor enhancing its signal transduction via the Smad1/5 protein pathway and interfering with ALK-5-Smad2/3 signaling [31,57-59]. Experiments performed on endothelial cells lacking the co-receptor endoglin, showed that these cells were not able to proliferate because the signalling path- way of TGF- $\beta 1$ that involves the activation of ALK-1 receptor is reduced, whereas the ALK-5 receptor signalling pathway is stimulated [57]. Then, expression of the coreceptor endoglin is essential to generate a proliferative cell response in the presence of TGF- $\beta 1$. It has been recently described that low doses of TGF- $\beta 1$ enhanced the expression of the early growth response factor-1 (egr1) and Krüppel-like factor 14 (KLF14) in TM3 Leydig cells [60]. Both KLF14 and egr-1 are transcription factors responsible for the regulation of the transcription of various genes. Scanning of the promoter region of endoglin gene, one site for egr-1 and eight sites for KLF family members were detected [60]. Egr-1 is involved in cell growth, differentiation, and survival [61]. In this context, Hou et al. [61] have reported that TGF- $\beta 1$ is able to induce a rapid and transient accumulation of egr- 1 protein and mRNA in human skin fibroblasts. On the other hand, it has been described that KLF14 is a protein upregulated by TGF- $\beta 1$ that represses TGF- $\beta$ RII [62]. The effect of TGF- $\beta 1$ on the induction of KLF14 and egr-1, promotes the expression of endoglin, which leads TGF$\beta 1$ to promote the signaling pathway of proliferation [60].

In addition, other factors involving hormonal regulation can modulate the expression of endoglin. It has been described in mouse Leydig cells, that progesterone is able to induce the expression of the co receptor endoglin [63] and, that the effect of low concentrations of TGF- $\beta 1$ plus progesterone showed an increased in the proliferating cell nuclear antigen (PCNA) expression and a decrease in Bax (pro-apoptotic gene) expression [63]. In the same work, the authors reported a clear increase in Smad1/5 phosporylation after mouse Leydig cell incubation with TGF- $\beta 1$ and progesterone [63]. In the testis, the control of the Leydig cell proliferation exerted by TGF$\beta 1$ was confirmed using the non-tumoral mouse Leydig cell line TM3. In this model, the gene expression of p15 was induced by low doses TGF- $\beta 1$ [60]. The presence of progesterone in the incubation media, induced the expression of endoglin and the proliferative marker PCNA and abolished the stimulatory effect of TGF- $\beta 1$ on p15 expression [60]. In this regard, it has been described that Smad proteins activate the transcription of $\mathrm{p} 15$, which inhibits CDK-6 and CDK-4 proteins, influencing the cellular cycle and leading to a quiescent state of the cells $[53,54,64]$. Therefore, the effects of TGF- $\beta 1$ on cell proliferation and cell cycle arrest would depend on the balance between ALK-1 and ALK-5 receptors and the expression of endoglin in the cell.

\section{EXPRESSION OF THE TGF- $\beta 1$ SYSTEM IN THE HYPERPLASIA OF LEYDIG CELLS}

It has been described in a variety of tissues that TGF- $\beta 1$ 
and its receptors are altered in pathological conditions such as cancer and hyperplasia [65]. The identification of factors involved in the progression of testicular pathologies such as Leydig cell hyperplasia (LCH) is crucial to understand this pathology.

Studies performed in experimental animals have shown that Leydig cell hyperplasia (LCH) may be induced by hormones and alterations in the production of paracrine growth factors [66]. It is known that LH, androgens or estrogens stimulate the proliferation of Leydig cells [67, 68]. Concerning this issue, it has been reported that Leydig cells of transgenic mice over-expressing TGF- $\beta 1$ are prominent [69]. In a model of transgenic mice over expressing hCG which show hyperplasia and hyperthtropy of Leydig cells, the expression of TGF- $\beta 1$, ALK- 1 and co receptor endoglin was increased respect to control animals [14]. Moreover, morphometric studies revealed that the "in vivo" intratesticular injection of normal mouse testis with TGFG- $\beta 1$ plus progesterone caused an increase in the volume of Leydig cells [63].

In patients with certain testicular pathologies, the histological patterns found are hypospermatogenesis, Germinal Arrest and Sertoli cells only Syndrome (SCO) with and without focus of spermatogenesis [70]. It has been reported that in some of these patients, Leydig cells show hyperplasia, characterized by the presence of small nodules, often bilateral, thus being a benign pathology for the patient [71]. Dobashi et al. [72] have described that the serum levels of TGF- $\beta 1$ were higher in patients with SCO than in normal controls. Gonzalez et al. [28] have shown that in patients that present LCH associated with SCO or hypospermatogenesis, the expression of TGF- $\beta 1$ protein and mRNA was higher than in patients with SCO or hipospermatogenesis alone.

Although the expression of TGF- $\beta 1$, TGF- $\beta$ RII and ALK-5 receptors has long been described [13,72], scarce information is known about the localization of ALK-1 and co receptor endoglin in human testis both in normal and pathological conditions. Recently, it has been describe the presence of ALK-1 receptor and co receptor endoglin in Leydig cells from normal and pathological testicular biopsies [28]. Moreover, an increased in the expression of these two receptors has been detected in patients with LCH [28].

\section{CONCLUSION}

In conclusion, the effect that TGF- $\beta 1$ exerts on the proliferation of Leydig cells does not primarily depend on factors such as the concentration of this cytokine in the cell environment, but more importantly, depends on the type of receptors and co receptors present in the Leydig cells. The description of the action of TGF- $\beta 1$ in the testis contributes to enlarging our knowledge on Leydig cell regulation and might be a clue to study signaling path- ways to key outcomes in male reproductive health.

\section{ACKNOWLEDGEMENTS}

This study was supported by Grants from Consejo Nacional de Investigaciones Científicas y Técnicas (CONI-CET), Agencia Nacional de Promoción Científica y Técnica (ANPCyT) and Facultad de MedicinaUniversidad de Buenos Aires, Argentina.

\section{REFERENCES}

[1] Massagué, J. and Wotton, D. (2000) Transcriptional control by TGF-/Smad signaling system. The EMBO Journal, 19, $1745-1754$.

http://dx.doi.org/10.1093/emboj/19.8.1745

[2] Lin, S.J., Lerch, T.F., Cook, R.W., Jardetzky, T.S. and Woodruff, T.K. (2006) The structural basis of TGF-beta, bone morphogenic protein, and activin ligand binding. Reproduction, 132, 179-190. http://dx.doi.org/10.1530/rep.1.01072

[3] Massagué, J. and Gomis, R.R. (2006) The logic of TGFbeta signaling. FEBS Letters, 580, 2811-2820. http://dx.doi.org/10.1016/j.febslet.2006.04.033

[4] Massagué, J. (1998) TGF-beta signal transduction. Annual Review of Biochemistry, 67, 753-791. http://dx.doi.org/10.1146/annurev.biochem.67.1.753

[5] Blobe, G.C., Schiemann, W.P. and Lodish, H.F. (2000) Role of transforming growth factor beta in human disease. New England Journal of Medicine, 342, 1350-1358. http://dx.doi.org/10.1056/NEJM200005043421807

[6] Ingman, W.V. and Robertson, S.A. (2002) Defining the actions of transforming growth factor beta in reproduction. Bioessays, 24, 904-914. http://dx.doi.org/10.1056/NEJM200005043421807

[7] ten Dijke, P., Hansen, P., Iwata, K.K., Pieler, C. and Foulkes, J.G. (1988) Identification of another member of the transforming growth factor type gene family. Proceeding of the National Academy of Science, 85, 4715-4719. http://dx.doi.org/10.1073/pnas.85.13.4715

[8] Feng, X.H. and Derynck, R. (2005) Specificity and versatility in TGF-beta signaling through Smads. Annual Review of Cell and Developmental Biology, 21, 659-693. http://dx.doi.org/10.1146/annurev.cellbio.21.022404.1420 18

[9] Itman, C., Mendis, S., Barakat, B. and Loveland, K.L. (2006) All in the family: TGF-family action in testis development. Reproduction, 132, 233-246. http://dx.doi.org/10.1530/rep.1.01075

[10] Gautier, C., Levacher, C., Saez, J.M. and Habert, R. (1997) Transforming growth factor beta1 inhibits steroidogenesis in dispersed fetal testicular cells in culture. Molecular and Cellular Endocrinology, 131, 21-30. http://dx.doi.org/10.1016/0303-7207(94)90146-5

[11] Gnessi, L., Fabbri, A. and Sprera, G. (1997) Gonadal peptides as mediators of development and functional control of the testis: An integrated system with hormones and local environment. Endocrine Review, 18, 541-609. http://dx.doi.org/10.1210/er.18.4.541 
[12] Avallet, O., Vigier, M., Leduque, P., Dubois, P.M. and Saez, J.M. (1994) Expression and regulation of transforming growth factor-beta 1 messenger ribonucleic acid and protein in cultured porcine Leydig and Sertoli cells. Endocrinology, 134, 2079-2087. http://dx.doi.org/10.1210/en.134.5.2079

[13] Zhang, Y.Q., He, X.Z., Zhang, J.S., Wang, R.A., Zhou, J. and $\mathrm{Xu}$, R.J. (2004) Stage-specific localization of transforming growth factor beta 1 and beta 3 and their receptors during spermatogenesis in men. Asian Journal of Androlology, 6, 105-109.

[14] Gonzalez, C.R., Gonzalez, B., Rulli, S.B., Huhtaniemi, I., Calandra, R.S. and Gonzalez-Calvar, S.I. (2010) TGF- $\beta 1$ system in Leydig cells. Part I: Effect of hCG and progesterone. Journal of Reproduction and Development, 56, 389-395. http://dx.doi.org/10.1262/jrd.09-166N

[15] Gonzalez, C.R., Calandra, R.S. and Gonzalez-Calvar, S.I. (2012) Influence of the photoperiod on TGF- $\beta 1$ and p15 expression in hamster Leydig cells. Reproductive Biology, 12, 201-218.

http://dx.doi.org/10.1016/S1642-431X(12)60086-2

[16] Teerds, K.J. and Dorrington, J.H. (1993) Localization of transforming growth factor 1 and 2 during testicular development in the rat. Biology of Reproduction, 48, 40-45. http://dx.doi.org/10.1095/biolreprod48.1.40

[17] Gautier, C., Levacher, C., Avallet, O., Vigier, M., Rouiller-Fabre, V., Lecerf, L., et al. (1994) Immunohistochemical localization of transforming growth factor-beta 1 in the fetal and neonatal rat testis. Molecular and Cellular Endocrinolology, 99, 55-61. http://dx.doi.org/10.1016/0303-7207(94)90146-5

[18] Caussanel, V., Tabone, E., Hendrick, J.C., Dacheux, F. and Benahmed, M. (1997) Cellular distribution of transforming growth factor betas 1, 2, and 3 and their types I and II receptors during postnatal development and spermatogenesis in the boar testis. Biology of Reproduction, 56, 357-367. http://dx.doi.org/10.1095/biolreprod56.2.357

[19] Shi, Y. and Massagué, J. (2003) Mechanisms of TGF-signaling from cell membrane to the nucleus. Cell, 113, 685-700. http://dx.doi.org/10.1016/S0092-8674(03)00432-X

[20] ten Dijke, P. and Hill, C.S. (2004) New insights into TGF-Smad signaling. Trends in Biochemical Sciences, 29, 265-273. http://dx.doi.org/10.1016/j.tibs.2004.03.008

[21] Suszko, M.I. and Woodruff, T.K. (2006) Cell-specificity of transforming growth factor-beta response is dictated by receptor bioavailability. Journal of Molecular Endocrinology, 36, 591-600. http://dx.doi.org/10.1677/jme.1.01936

[22] de Caestecker, M. (2004) The transforming growth factor-beta superfamily of receptors. Cytokine Growth Factor Review, 15, 1-11. http://dx.doi.org/10.1016/j.cytogfr.2003.10.004

[23] Frazen, P., ten Dijke, P., Ichijo, H., Yamashita, H., Schulz, P., Heldin, C.H., et al. (1993) Cloning of a TCF type I receptor that forms a heteromeric complex with the TGF type II receptor. Cell, 75, 681-692. http://dx.doi.org/10.1016/0092-8674(93)90489-D

[24] Lux, A., Attisano, L. and Marchuk, D.A. (1999) Assign- ment of transforming growth factor 1 and 3 and a third new ligand to the type I receptor ALK-1. Journal of Biological Chemistry, 274, 9984-9992. http://dx.doi.org/10.1074/jbc.274.15.9984

[25] Oh, S.P., Seki, T., Goss, K.A., Imamura, T., Yi, Y., Donahoe, P.K., et al. (2000) Activin receptor like kinase 1 (ALK-1) modulates TGF 1 signalling in regulation of angiogenesis. Proceeding of the National Academic of Science, 97, 2626-2631.

http://dx.doi.org/10.1073/pnas.97.6.2626

[26] Olaso, R., Pairault, C. and Habert, R. (1998) Expression of type I and II receptors for transforming growth factor beta in the adult rat testis. Histochemistry and Cell Biology, 110, 613-618. http://dx.doi.org/10.1007/s004180050324

[27] Goddard, I., Bouras, M., Keramidas, M., Hendrick, J.C., Feige, J.J. and Benahmed, M. (2000) Transforming growth factor-beta receptor types I and II in cultured porcine Leydig cells: Expression and hormonal regulation. Endocrinology, 141, 2068-2074.

http://dx.doi.org/10.1210/en.141.6.2068

[28] Gonzalez, C.R., Matzkin, M.E., Frungieri, M.B., Terradas, C., Ponzio, R., Puigdomenech, E., et al. (2010) Expression of the TGF-beta1 system in human testicular pathologies. Reproductive Biology and Endocrinology, 8, 148159. http://dx.doi.org/10.1186/1477-7827-8-148

[29] Wang, X.F., Lin, H.Y., Ng-Eaton, E., Downward, J., Lodish, H.F. and Weinberg, R.A. (1991) Expression cloning and characterization of the TGF-beta type III receptor. Cell, 67, 797-805. http://dx.doi.org/10.1016/0092-8674(91)90074-9

[30] Gougos, A. and Letarte, M. (1990) Primary structure of endoglin, an RGD-containing glycoprotein of human endothelial cells. Journal of Biological Chemistry, 265, 8361-8364.

[31] Koleva, R.I., Conley, B.A., Romero, D., Riley, K.S., Marto, J.A., Lux, A., et al. (2006) Endoglin structure and function: Determinants of endoglin phosphorylation by transforming growth factor-beta receptors. Journal of $\mathrm{Bi}$ ological Chemistry, 281, 25110-25123. http://dx.doi.org/10.1074/jbc.M601288200

[32] MacConel, L.A., Leal, A.L. and Vale, W.W. (2002) The distribution of betaglycan protein and mRNA in rat brain, pituitary, and gonads: implications for a role for betaglycan in inhibin-mediated reproductive functions. Endocrinology, 143, 1066-1075. http://dx.doi.org/10.1210/en.143.3.1066

[33] Lebrin, F., Goumans, M.J., Jonker, L., Carvalho, R.L., Valdimarsdottir, G., Thorikay, M., et al. (2004) TGF-beta/ ALK1 Endoglin promotes endothelial cell proliferation and signal transduction. The EMBO Journal, 23, 40184028. http://dx.doi.org/10.1038/sj.emboj.7600386

[34] Mathews, L.S. and Vale, W.W. (1993) Characterization of type II activin receptors. Binding, processing and phosphorylation. Journal of Biological Chemistry, 268, 1901319018.

[35] Chen, R.H. and Derynck, R. (1994) Homomeric interactions between the type II TGF-receptors. Journal of Biological Chemistry, 269, 22868-22874. 
[36] Massagué, J. (2000) How cells read TGF-beta signals. Nature Reviews. Molecular Cell Biology, 1, 169-178.

[37] Massagué, J., Seoane, J. and Wotton, D. (2005) Smad transcription factors. Genes \& Development, 19, 27832810. http://dx.doi.org/10.1101/gad.1350705

[38] Xu, J., Beyer, A.R., Walker, W.H. and McGee, E.A. (2003) Developmental and stage-specific expression of Smad2 and Smad3 in rat testis. Journal of Andrology, 24, 192-200.

[39] Maire, M., Florin, A., Kaszas, K., Regnier, D., Contard, P., Tabone, E., et al. (2005) Alteration of transforming growth factor-beta signaling system expression in adult rat germ cells with a chronic apoptotic cell death process after fetal androgen disruption. Endocrinology, 146, 5135-5143. http://dx.doi.org/10.1210/en.2005-0592

[40] Zhao, G.Q. and Hogan, B.L.M. (1997) Evidence that Mothers-against-dpp-related 1 (Madr1) plays a role in the initiation and maintenance of spermatogenesis in the mouse. Mechanisms of Development, 61, 63-73. http://dx.doi.org/10.1016/S0925-4773(96)00622-3

[41] Pellegrini, M., Grimaldi, P., Rossi, P., Germia, R. and Dolci, S. (2003) Development expression of BMP4/ ALK3/SMAD5 signaling pathway in the mouse testis: A potential role of BMP4 in spermatogonia differentiation. Journal of Cell Science, 116, 3363-3372. http://dx.doi.org/10.1242/jcs.00650

[42] Sun, T., Xin, Z., Jin, Z., Wu, Y. and Gong, Y. (2008) Effect of TGF- $\beta /$ Smad signalling on Sertoli Cell and possible mechanism related to complete Sertoli Cell-only Syndrome. Molecular and Cellular Biochemistry, 319, 1-7. http://dx.doi.org/10.1007/s11010-008-9869-3

[43] Derynck, R. and Feng, X.H. (1997) TGF-receptor signaling. Biochimica et Biophysica Acta, 1333, F105-F150.

[44] Javelaud, D. and Mauviel, A. (2005) Crosstalk mechanisms between the mitogen-activated protein kinase pathways and Smad signaling downstream of TGF- $\beta$ : Implications for carcinogenesis. Oncogene, 24, 5742-5750. http://dx.doi.org/10.1038/sj.onc.1208928

[45] Wu, D.T., Bitzer, M., Ju, W., Mundel, P. and Bottinger, E.P. (2005) TGF- $\beta$ concentration specifies differential signaling profiles of growth arrest/differentiation and apoptosis in podocytes. Journal of the American Society of Nephrology, 16, 3211-3221. http://dx.doi.org/10.1681/ASN.2004121055

[46] Yan, Z., Winawer, S. and Friedman, E. (1994) Two different signal transduction pathways can be activated by transforming growth factor beta 1 in epithelial cells. Journal of Biological Chemistry, 269, 13231-13237.

[47] Zhang, Y.E. (2009) Non-Smad pathways in TGF-beta signaling. Cellular Research, 19, 128-139. http://dx.doi.org/10.1038/cr.2008.328

[48] Yu, L., Hébert, M.C. and Zhang, Y.E. (2002) TGF-beta receptor-activated p38 MAP kinase mediates Smad-independent TGF-beta responses. The EMBO Journal, 21, 3749-3759. http://dx.doi.org/10.1093/emboj/cdf366

[49] Itoh, S., Thorikay, M., Kowanetz, M., Moustakas, A., Itoh, F. and Heldin, C.H. (2003) Elucidation of Smad requirement in transforming growth factor-beta type I re- ceptor-induced responses. Journal of Biological Chemistry, 278, 3751-3761.

http://dx.doi.org/10.1074/jbc.M208258200

[50] Huang, S.S. and Huang, J.S. (2005) TGF-beta control of cell proliferation. Journal of Cellular Biochemistry, 96, 447-462. http://dx.doi.org/10.1002/jcb.20558

[51] Rich, J.N., Zhang, M., Datto, M.B., Bigner, D.D. and Wang, X.F. (1999) Transforming growth factor-beta-mediated $\mathrm{p} 15^{\mathrm{INK} 4 \mathrm{~B}}$ induction and growth inhibition in astrocytes is SMAD3-dependent and a pathway prominently altered in human glioma cell lines. Journal of Biological Chemistry, 274, 35053-35058. http://dx.doi.org/10.1074/jbc.274.49.35053

[52] Robson, C.N., Gnanapragasam, V., Byrne, R.L. and Collins, A.T. (1999) Transforming growth factor-beta 1 up-regulates p15, p21 and p27 and blocks cell cycling in G1 in human prostate epithelium. Journal of Endocrinology, 160, 257-266. http://dx.doi.org/10.1677/joe.0.1600257

[53] Li, X., Zhang, Y.Y., Wang, Q. and Fu, S.B. (2005) Association between endogenous gene expression and growth regulation induced by TGF-beta1 in human gastric cancer cells. World Journal of Gastroenterology, 11, 61-68.

[54] Li, Z., Chen, Y., Cao, D., Wang, Y., Chen, G., Zhang, S., et al. (2002) Glucocorticoid up-regulates transforming growth factor-beta (TGF-beta) type II receptor and enhances TGF-beta signaling in human prostate cancer PC-3 cells. Endocrinology, 147, 5259-5267. http://dx.doi.org/10.1210/en.2006-0540

[55] Dunfield, L.D., Dwyer, E.J. and Nachtigal, M.W. (2002) TGF beta-induced Smad signaling remains intact in primary human ovarian cancer cells. Endocrinology, 143, 1174-1181. http://dx.doi.org/10.1210/en.143.4.1174

[56] Pastor, L.M., Zuasti, A., Ferrer, C., Bernal-Mañas, C.M., Morales, E., Beltrán-Frutos, E., et al. (2011) Proliferation and apoptosis in aged and photoregressed mammalian seminiferous epithelium, with particular attention to rodents and humans. Reproduction in Domestic Animals, 46, 155164. http://dx.doi.org/10.1111/j.1439-0531.2009.01573.x

[57] Lebrin, F., Deckers, M., Bertolino, P. and ten Dijke, P. (2005) TGF- $\beta$ receptor function in the endothelium. Cardiovascular Research, 65, 599-608. http://dx.doi.org/10.1016/j.cardiores.2004.10.036

[58] Gougos, A. and Letarte, M. (1990) Primary structure of endoglin, an RGD-containing glycoprotein of human endothelial cells. Journal of Biological Chemistry, 265, 8361-8364.

[59] Blanco, F.J., Santibanez, J.F., Guerrero-Esteo, M., Langa, C., Vary, C.P. and Bernabeu, C. (2005) Interaction and functional interplay between endoglin and ALK-1, two components of the endothelial transforming growth factor-beta receptor complex. Journal of Cell Physiology, 204, 574-584. http://dx.doi.org/10.1002/jcp.20311

[60] Gonzalez, C.R., Vallcaneras, S.S., Calandra, R.S. and Gonzalez-Calvar, S.I. (2013) Involvement of KLF14 and egr-1 in the TGF-beta1 action on Leydig cell proliferation. Cytokine, 61, 670-675. http://dx.doi.org/10.1016/j.cyto.2012.12.009

[61] Hou, X., Arvisais, E.W., Jiang, C., Chen, D., Roy, S.K., 
Pate, J.L., et al. (2008) Prostaglandin F2 $\alpha$ stimulates the expression and secretion of transforming growth factor B1 via induction of the early growth response 1 gene (EGR1) in the bovine corpus luteum. Molecular Endocrinology, 22, 403-414. http://dx.doi.org/10.1210/me.2007-0272

[62] Truty, M.J., Lomberk, G., Fernandez-Zapico, M.E. and Urrutia, R. (2009) Silencing of the transforming growth factor-beta (TGFbeta) receptor II by Krüppel-like factor 14 underscores the importance of a negative feedback mechanism in TGFbeta signaling. Journal Biological Chemistry, 284, 6291-6300. http://dx.doi.org/10.1074/jbc.M807791200

[63] Gonzalez, C.R., Gonzalez, B., Rulli, S.B., Dos Santos, M.L., Mattos Jardim Costa, G., França, L.R., et al. (2010) TGF-beta1 system in Leydig Cells. Part II: TGF-beta1 and progesterone, through Smad1/5, are involved in the hyperplasia/hypertrophy of Leydig cells. Journal of Reproduction and Development, 56, 400-404.

[64] Feng, X.-H., Lin, X. and Derynck, R. (2000) Smad2, Smad3 and Smad4 cooperate with Sp1 to induce p15 $15^{\text {Ink4B }}$ transcription in response to TGF-beta. The EMBO Journal, 19, 5178-5193. http://dx.doi.org/10.1093/emboj/19.19.5178

[65] Kim, I.Y., Kim, M.M. and Kim, S.-J. (2005) Transforming growth factor- $\beta$ : Biology and clinical relevance. Journal of Biochemistry and Molecular Biology, 38, 1-8. http://dx.doi.org/10.5483/BMBRep.2005.38.1.001

[66] Clegg, E.D., Cook, J.C., Chapin, R.E., Foster, P.M. and Daston, G.P. (1997) Leydig cell hyperplasia and adenoma formation: Mechanisms and relevance to humans. Reproductive Toxicology, 11, 107-121. http://dx.doi.org/10.1016/S0890-6238(96)00203-1
[67] Ge, R.S. and Hardy, M.P. (1997) Decreased cyclin $A_{2}$ and increased cyclin $\mathrm{G}_{1}$ levels coincide with loss of proliferative capacity in rat Leydig cells during pubertal development. Endocrinology, 138, 3719-3726. http://dx.doi.org/10.1210/en.138.9.3719

[68] Gould, M.L., Hurst, P.R. and Nicholson, H.D. (2007) The effects of oestrogen receptors alpha and beta on testicular cell number and steroidogenesis in mice. Reproduction, 134, 271-279. http://dx.doi.org/10.1530/REP-07-0025

[69] Sanderson, N., Factor, V., Nagy, P., Kopp, J., Kondaiah, P., Wakefield, L., et al. (1995) Hepatic expression of mature transforming growth factor beta 1 in transgenic mice results in multiple tissue lesions. Proceedings of the $\mathrm{Na}$ tional Academic of Science USA, 92, 2572-2576.

[70] Anniballo, R., Ubaldi, F., Cobellis, L., Sorrentino, M., Rienzi, L., Greco, E., et al. (2000) Criteria predicting the absence of spermatozoa in the Sertoli Cell-only Syndrome can be used to improve success rates of sperm retrieval. Human Reproduction, 15, 2269-2277. http://dx.doi.org/10.1093/humrep/15.11.2269

[71] Carucci, L.R., Tirkes, A.T., Pretorius, E.S., Genega, E.M. and Weinstein, S.P. (2003) Testicular Leydig's cell hyperplasia: MR imaging and sonographic findings. AJR American Journal of Roentgenology, 180, 501-503. http://dx.doi.org/10.2214/ajr.180.2.1800501

[72] Dobashi, M., Fujisawa, M., Yamasaki, T., Okada, I. and Kamido. S. (2002) Distribution of intracellular and extracellular expression of transforming growth factorb1 (TGF- $\beta 1$ ) in human testis and their association with spermatogenesis. Asian Journal of Andrology, 4, 105-109. 